\title{
Spatial Based Industry and Warehousing Potential in Tanjungpinang City
}

\author{
Adji Suradji Muhammad ${ }^{1}$, Rizky Gunawan ${ }^{2}$, Maullana Chandra Atmajha ${ }^{3}$, Mahadiansar ${ }^{4}$ \\ \{ $\underline{\text { suradji @umrah.ac.id }}{ }^{1}$, wrlord23@gmail.com² ${ }^{2}$, maullanachandraatmajha@gmail.com ${ }^{3}$, \\ mahadiansar@student.ub.ac.id $\left.{ }^{4}\right\}$
}

${ }^{1}$ Raja Ali Haji Maritime University, ${ }^{2}$ Raja Ali Haji Maritime University, ${ }^{3}$ Raja Ali Haji Maritime University, ${ }^{4}$ Brawijaya University

\begin{abstract}
As the Capital of the Riau Archipelago Province, Tanjungpinang City is still in crucial need of various investments to support facilities and infrastructure for economic development, especially in the Industrial and Warehousing sectors. Various problems occur such as infrastructure development, development of facilities and development of human resources related to ports. It is necessary to do considering the number of ships are leaned getting bigger. This study aims to analyze the investment potential related to the industrial and warehousing sectors which spreading across Tanjungpinang city. For primary data, the research method used was questionnaires given to each sub-district in Tanjungpinang City using the AHP (Analytic Hierarchy Process) method to compare one option with another. Secondary data was collected from documents that have legality, statistical data, and spatial data. The results of this study can provide input for industry and warehousing in Tanjungpinang City to provide funding for economic development.
\end{abstract}

Keywords: Spatial; Industry; Warehousing Potential; Tanjungpinang City

\section{Introduction}

The increase in real estate investment in the logistics and industrial sectors reflects the changing strategy users are adopting for higher-quality assets. In addition, there is a shift in the composition of new economic users, which is largely influenced by the growth of ecommerce and the supply chain supported by technology [1]. The growing portfolio and the number of large transactions as well as several macroeconomic factors contributed to the increase in investment volume. The urban population in the Asia Pacific is expected to increase by 41 million per year between 2020-2025 [2]. In the same period, there will be 760 million new middle-class people whose income will grow 4 percent per year. This shows significant growth potential for the sector.

Tanjungpinang City is a capital city located on Bintan Island, Riau Islands Province. The Riau Islands Province consists of nine islands; four islands are inhabited and five are uninhabited [3]. Due to its proximity to Malaysia and Singapore, Tanjungpinang is ideally located as an investment center to contribute to the economy through the industrial and warehousing sectors. The Gross Regional Domestic Product (GRDP) in the Industrial and Warehousing sector located in Tanjungpinang City, contributed 7\% of the GRDP in 2019[4]. This is still far from the Construction, Wholesale and Retail sectors which contributed $29 \%$. However, so far in 2019 Construction, Wholesale, and Retail have not provided significant 
economic growth. Due to the location of investment priority do not have adequate facilities, thus affected on developing in the field of wholescale and retail scale trading [5]. [6]. To tackle this issue and increase the local economy, the Tanjungpinang City government allocated additional land for investment in the industrial and warehousing sectors.

This study aims to analyze the investment obtained in the industrial and warehousing sectors widely distributed because of the local government adding priority locations. This support can be facilitated by mapping investment potential so that investment entering the Tanjungpinang area is in accordance with the Tanjungpinang City Regional Regulation Number 3 of 2018 concerning Detailed Spatial Planning and Zoning Regulations in Tanjungpinang City, West Tanjungpinang, East Tanjungpinang, and Bukit Bestari Districts 2018-2038. With the results of this study, the Tanjungpinang City government is able to understand the potential of the industrial and warehousing sectors by understanding the Analytical Hierarchy Process (AHP) method and spatial data [7] so that the issues that arise in the industrial and warehousing sectors can have an effect on the community and become a driving force for economic progress in Tanjungpinang City.

\section{Data and Method}

\subsection{Data}

The data is taken and used through investment analysis in the industrial and warehousing sectors from four villages: Dompak Village, Tanjung Unggat Village, Kampung Bulang Village, and Air Raja Village. Figure 1.1 presents the locations of the four villages. It can be clearly seen that priority locations are currently lacking. By considering various issues such as investment for construction, development, and improvement of port services, it is necessary to determine priority locations. The data processed in 2020 illustrates the importance and increasing the potential for Industry and Warehousing development.

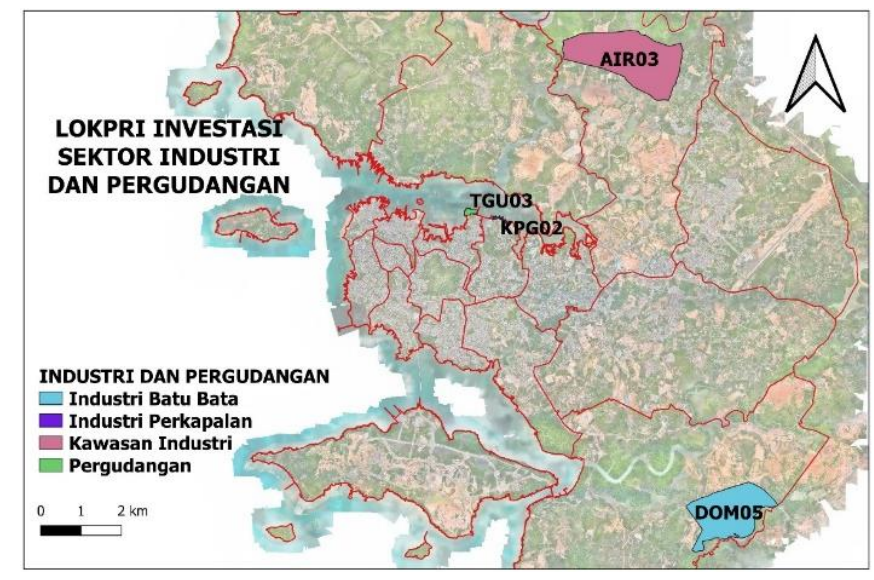

Fig.1. Distribution of Priority Locations Based on the Investment and Warehousing Sector

\subsection{Method}


Several methods were used in this research to collect secondary and primary data. Secondary data came from documents with legal, statistical, and spatial data. Primary data was obtained through a questionnaire given to each sub-district in Tanjungpinang City using the AHP (Analytic Hierarchy Process) method combined with GIS [8]. One of the priority investment sectors is the Industry and Warehousing sector. As the name suggests, the Analytical Hierarchy Process or AHP is an analytical technique in making decisions based on hierarchical criteria [9][10]. The AHP analysis technique is arranged based on the desired goals/results, then proceeds by making criteria starting from level 1 as the first layer of goal determination. In some cases, the criteria items at level 1 clarified by the addition of several sub-criteria at level 2 and function as a second layer. The structure in this hierarchy can be continued at level 3 and so on depending on the needs. The formula is stated as follows:

$$
W_{i}^{s}=\sum_{j=1}^{j=m} w_{i, j}^{s} w_{j}^{a}
$$

Where:

$$
\begin{aligned}
& W_{-} i^{\wedge} s=\text { total weight of all locations } \\
& w_{-}(i, j) \wedge s=\text { weight of one alternative location } i \text { associated with an attribute layer } j \\
& w_{-} j^{\wedge} a=\text { weight of attribute } j \\
& m=\text { number of attributes } \\
& n=\text { number of locations }
\end{aligned}
$$

Furthermore, the criteria used in the AHP process are stated in Figure 2.1 which is a flow chart that explains the AHP process in the preparation of documents, namely:

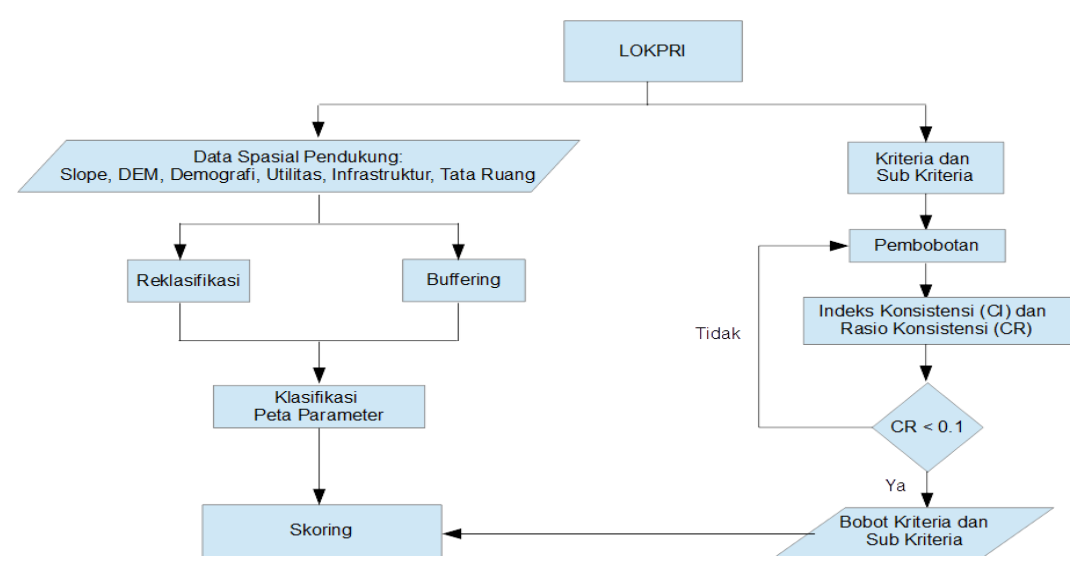

Fig. 2. Flow Chart of Priority Location Determination Based on AHP 


\section{Results and Discussion}

\subsection{Result of AHP Calculation of Industrial and Warehousing Sector}

The hierarchy for all levels of AHP criteria for the Industrial and Warehousing sector is stated in Figure 3.1 below.

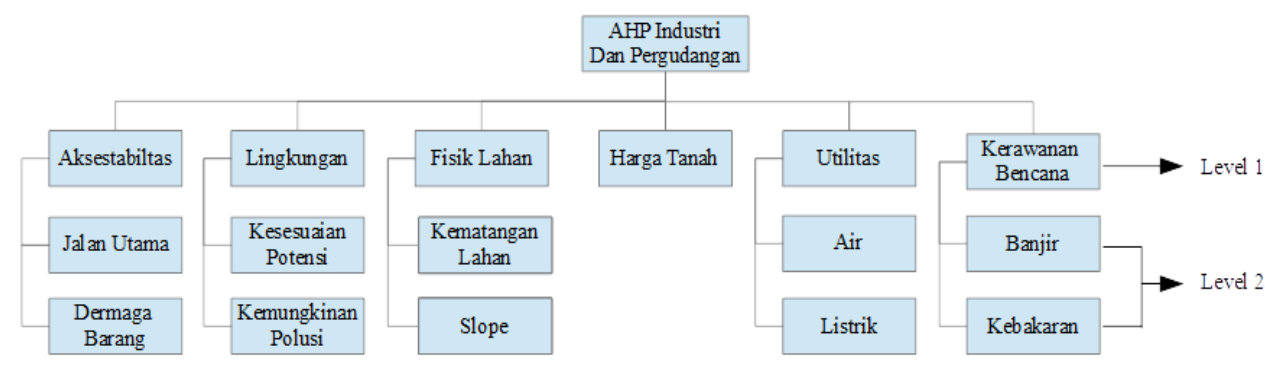

Fig.3. Hierarchical Structure in AHP in the Industrial and Warehousing Sector

\subsubsection{Finding Criteria Weights at Level 1}

Tabulation that presents PCM and EV in the Industrial and Warehousing sector as Tables 1 and 2 below:

Table 1. Pairwise Comparison Matrix (PCM) in the Industrial and Warehousing Sector

\begin{tabular}{lcccccc}
\hline \multicolumn{1}{c}{ Criteria } & Accessibility & Environment & $\begin{array}{c}\text { Land } \\
\text { Physical }\end{array}$ & $\begin{array}{c}\text { The land } \\
\text { price }\end{array}$ & Utilities & $\begin{array}{c}\text { Disaster } \\
\text { Vulnerability }\end{array}$ \\
\hline Accessibility & 1.00 & 1.00 & 1.29 & 1.29 & 1.13 & 1.29 \\
Environment & 1.00 & 1.00 & 1.29 & 1.29 & 1.13 & 1.29 \\
Physical Land & 0.78 & 0.78 & 1.00 & 1.00 & 0.88 & 1.00 \\
The land price & 0.78 & 0.78 & 1.00 & 1.00 & 0.88 & 1.00 \\
Utilities & 0.89 & 0.89 & 1.14 & 1.29 & 1.00 & 1.14 \\
Disaster & 0.78 & 0.78 & 1.00 & 1.00 & 0.88 & 1.00 \\
Vulnerability & 5.22 & 5.22 & 6.71 & 6.86 & 5.88 & 6.71 \\
& & & & &
\end{tabular}

Table 2. Matrix of Eigenvalues in the Industrial and Warehousing Sector

\begin{tabular}{lcccccc}
\hline \multicolumn{1}{c}{ Criteria } & Accessibility & Environment & $\begin{array}{c}\text { Physical } \\
\text { Land }\end{array}$ & $\begin{array}{c}\text { The land } \\
\text { price }\end{array}$ & Utilities & $\begin{array}{c}\text { Disaster } \\
\text { Vulnerability }\end{array}$ \\
\hline Accessibility & 0.19 & 0.19 & 0.19 & 0.19 & 0.19 & 0.19 \\
Environment & 0.19 & 0.19 & 0.19 & 0.19 & 0.19 & 0.19 \\
Physical Land & 0.15 & 0.15 & 0.15 & 0.15 & 0.15 & 0.15 \\
The land price & 0.15 & 0.15 & 0.15 & 0.15 & 0.15 & 0.15 \\
Utilities & 0.17 & 0.17 & 0.17 & 0.19 & 0.17 & 0.17 \\
Disaster & & & & & & \\
Vulnerability & 0.15 & 0.15 & 0.15 & 0.15 & 0.15 & 0.15 \\
& 1.00 & 1.00 & 1.00 & 1.00 & 1.00 & 1.00 \\
\hline
\end{tabular}




\subsubsection{Calculation of Consistency Ratio}

The calculation of the Consistency Ratio (CR) for AHP in the Industrial and Warehousing sector is listed in the steps below:

Table 3. Calculation of max in the Industrial and Warehousing Sector

\begin{tabular}{llc}
\hline $\begin{array}{c}\text { Weighted Sum Values } \\
(W S V=P C M \times C W)\end{array}$ & WSV/CW & $\begin{array}{c}\lambda \max \\
\text { (Average of WSV/CW) }\end{array}$ \\
\hline 1.14893617 & 6 & \\
1.14893617 & 6 & 6.020833 \\
0.893617021 & 6 & \\
0.893617021 & 6 & \\
1.042553191 & 6.125 & \\
0.893617021 & 6 & \\
\hline
\end{tabular}

$$
\begin{aligned}
& \text { Index }(C I) \\
& C I=\frac{\lambda \max -n}{n-1} \\
& C I=6.020833-6 /(6-1) \\
& C I=0.004166667 \\
& \text { Random Index }(R I) \\
& R I=\frac{1.98(n-2)}{n} \\
& R I=(1.98(6-2)) / 6=1.32
\end{aligned}
$$

- Consistency Ratio (CR)

$$
C R=C I / R I
$$

$$
\begin{aligned}
& C R=0.004166667 / 1.32 \\
& C R=0.003157
\end{aligned}
$$

CR value less than 0.1 indicates the weight of the criteria is consistent and feasible to use.

\subsubsection{Criteria Weights at Level 2}

Table 4 Criteria Weight Level 2 in the Industrial and Warehousing Sector will present the $\mathrm{CW}$ value for the level 2 criteria for the industrial and warehousing sector.

Table 4. Criteria Weight Level 2 in the Industrial and Warehousing Sector

\begin{tabular}{llc}
\hline Level 1 Criteria & \multicolumn{1}{c}{ Level 2 Criteria } & $\begin{array}{c}\text { Criteria } \\
\text { Weight }\end{array}$ \\
\hline Accessibility & Distance to Main Street & 0.5 \\
& Distance to Freight Wharf & 0.5 \\
Economy & Potential Suitability & 0.5 \\
& Possible Pollution & 0.5 \\
Physical Land & Land Maturity & 0.5 \\
& Slope & 0.5 \\
Land Price & & 1 \\
Utilities & Water & 0.69
\end{tabular}




\begin{tabular}{lll} 
& Electricity & 0.31 \\
Disaster & Flood & 0.67 \\
Vulnerability & Fire & 0.33 \\
\hline
\end{tabular}

\subsubsection{Weighting}

The weighting is carried outby determining the score on each variable with the lowest criteria (in this case, level 2). The weighting scale for each variable has a hierarchy at level 2 AHP in the industrial and warehousing sectors as contained in Appendix 3-AHP Criteria. The following are some of the methods used in selecting the most suitable scale for each criterion variable (arranged by classification at level 1):

1. The method used in allocating the score for each criterion

2. Accessibility: Main Road buffering, Freight dock buffering (Sri Payung Harbor)

3. Environment: Overlay housing, Observation and Discussion

4. Physical Land: Observation and discussion, Overlay Slope

5. Land Price: Observation and discussion

6. Utilities: Observation and Discussion

7. Disaster Vulnerability: Observation and Discussion, DEM Overlay

\subsubsection{Final Calculation}

Table 5 scores of each Priority Location for Each Criteria in the Industrial and Warehousing Sector will present the value of each criterion for level 2 for each industrial and warehousing Priority Location.

Table 5. Scores of Each Priority Location on Each Criteria in the Industrial and Warehousing Sector

\begin{tabular}{|c|c|c|c|c|c|c|c|c|c|c|c|}
\hline 目 & 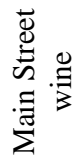 & 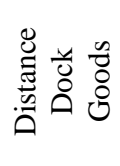 & $\begin{array}{l}\text { তे } \\
\text { गे } \\
0\end{array}$ & 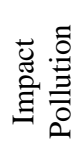 & 氖 & $\frac{\ddot{a}}{n}$ & 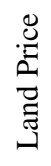 & $\frac{\bar{\Xi}}{\bar{z}}$ & 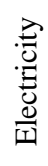 & $\begin{array}{l}\overrightarrow{8} \\
\frac{0}{I}\end{array}$ & 坣 \\
\hline AIR03 & 3 & 3 & 5 & 5 & 5 & 5 & 5 & 5 & 5 & 5 & 5 \\
\hline DOM05 & 5 & 1 & 5 & 5 & 5 & 3 & 5 & 5 & 3 & 5 & 5 \\
\hline KPG02 & 1 & 5 & 5 & 3 & 3 & 5 & 1 & 5 & 5 & 5 & 3 \\
\hline TGU03 & 1 & 5 & 5 & 5 & 3 & 5 & 1 & 5 & 5 & 5 & 5 \\
\hline
\end{tabular}

The following is the WLC equation used for carrying out the final calculation in assessing investment ratings in the industrial and warehousing sectors. The final calculation is

$$
W_{i}^{s}=\sum_{j=1}^{j=m} w_{i, j}^{s} w_{j}^{a}
$$




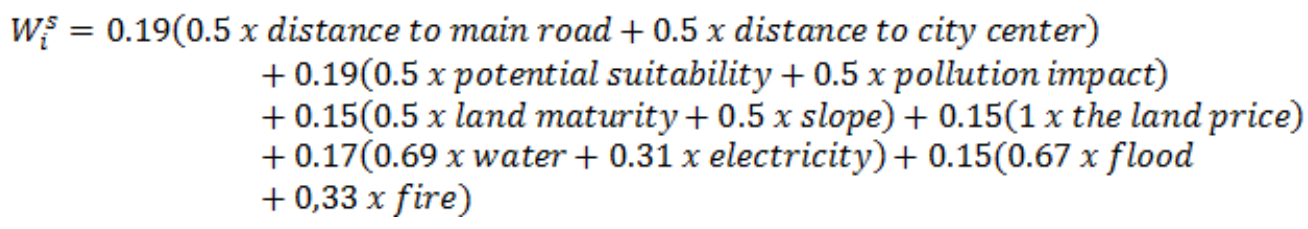

Table 6. Final Score and Ranking of Industrial and Warehousing Priority Location

\begin{tabular}{|c|c|c|c|c|c|c|c|}
\hline A & 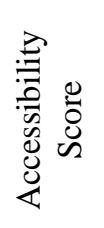 & 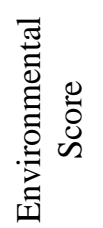 & 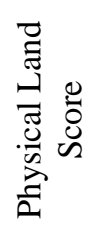 & 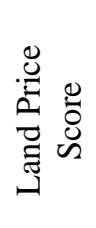 & 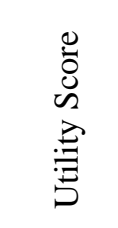 & 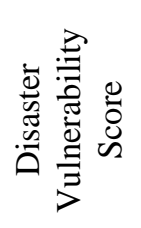 & 胥 \\
\hline AIR03 & 0.57 & 0.95 & 0.75 & 0.75 & 0.85 & 0.75 & 4.62 \\
\hline DOM05 & 0.57 & 0.95 & 0.6 & 0.75 & 0.7446 & 0.75 & 4.3646 \\
\hline TGU03 & 0.57 & 0.95 & 0.6 & 0.15 & 0.85 & 0.75 & 3.87 \\
\hline KPG02 & 0.57 & 0.76 & 0.6 & 0.15 & 0.85 & 0.651 & 3.581 \\
\hline
\end{tabular}

\subsection{Discussion on Calculation of AHP in the Industrial and Warehousing Sector}

Tanjungpinang City is a developing area that still needs basic infrastructure to support economic activities. One of the supporting infrastructure facilities is the port. Currently, port services in Tanjungpinang are not maximum and require investment for the construction, development, and improvement of port services. On the other hand, the number of cargo ships entering Tanjungpinang City is increasing day by day. Many incoming cargo ships require efficient port services ranging from loading and unloading services, warehousing services, and ship repair services. In addition, there is many incoming raw materials opening opportunities for the industrial sector.

Addressing this issue is the target of investors to develop the industry and warehousing sectors. The analysis of investment in the industrial and warehousing sector is intended to identify several factors including:

1. Port Distribution.

2. Distribution of raw materials.

3. Industry and warehousing sector investment category.

Based on the results of the analysis, the warehousing sectors, the shipping sectors, and the raw building materials still provide investment opportunities. Potential locations for investment in industry and warehousing are Dompak Village, Tanjung Unggat Village, Kampung Bulang Village, and Air Raja Village. 


\section{Conclusions and Suggestions}

\subsection{Conclusions}

Based on the results of research that has been processed and analyzed, several conclusions can be drawn. Firstly, the Investment Potential Map shows that it is beneficial for the local economy for investors to develop the Industrial and Warehousing sector. Secondly, an information system is needed to facilitate investors in determining the most suitable location according to the type of investment to be given or invested. Thirdly, the Industrial and Warehousing Sector are one of the attractions in strengthening investment in Tanjungpinang City.

\subsection{Suggestion}

Based on the findings of this research, it is recommended that the Tanjungpinang City government should specify the priority investment locations to potential investors and require investors to show sustainable investment plans. To achieve this, the Riau Islands Provincial Government, and the Bintan Free Trade Zone Management Agency in the Tanjungpinang region must coordinate and cooperate to explore and promote the investment potential in Tanjungpinang City.

\section{References}

[1] Hidayat, R. (2014). Rancang Bangun Sistem Informasi Logistik. Jurnal Optimasi Sistem Industri, 13(2088-4842), 707-724.

[2] Saracoglu, B. O. (2013). Selecting industrial investment locations in master plans of countries. European Journal of Industrial Engineering, 7(4), 416-441.

[3] Budiman, S., Setyadiharja, R., A Karim, Z., \& Mukhlis, S. (2020). Analysis of regional investment policy direction in the general investment plan perspective of Tanjungpinang City.

[4] Leyn, Y. G. S. (2018). Kerjasama IMS-GT (Indonesia Malaysia Singapore-Growth Triangle) Dalam Meningkatkan Pertumbuhan Ekonomi Batam (Doctoral Dissertation, Perpustakaan).

[5] Prastya, I. Y., \& Kustiawan, K. (2015). Analisis Pelaksanaan Kebijakan Free Trade Zone (FTZ) di Kawasan Kota Tanjungpinang Kepulauan Riau. Jurnal Ilmu Administrasi Negara (JUAN), 3(2), 42-50.

[6] Sen, A., \& Jacob, V. S. (1998). Industrial-strength data warehousing. Communications of the ACM, 41(9), 28-31.

[7] Palcic, I., \& Lalic, B. (2009). Analytical Hierarchy Process as a tool for selecting and evaluating projects. International Journal of Simulation Modelling (IJSIMM), 8(1).

[8] Saaty, T. L. (2003). Decision-making with the AHP: Why is the principal eigenvector necessary. European journal of operational research, 145(1), 85-91.

[9] Cheung, S. O., Lam, T. I., Leung, M. Y., \& Wan, Y. W. (2001). An analytical hierarchy process-based procurement selection method. Construction Management \& Economics, 19(4), 427-437. 
[10] Vahidnia, M. H., Alesheikh, A., Alimohammadi, A., \& Bassiri, A. (2008). Fuzzy analytical hierarchy process in GIS application. The International Archives of the Photogrammetry, Remote Sensing and Spatial Information Sciences, 37(B2), 593-596. 